\title{
ICT Usage and Business Performance of SMEs in Sri Lanka: The Mediation Effect of Bounded Rationality
}

\author{
R.V.S.P.K. Ranatunga ${ }^{1}$, H.M.S. Priyanath ${ }^{2}$ \& R.G.N. Megama $^{3}$ \\ ${ }^{1}$ Center for Computer Studies, \\ Sabaragamuwa University of Sri Lanka, Belihuloya, \\ SRI LANKA \\ ${ }^{2}$ Department of Economics and Statistics, \\ Sabaragamuwa University of Sri Lanka, Belihuloya, \\ SRI LANKA \\ ${ }^{3}$ Department of Computer Science, \\ University of Sri Jayewardenepura, \\ SRI LANKA \\ *corresponding: spkr@ccs.sab.ac.lk
}

\begin{abstract}
The study examined empirically how Information \& Communication Technology (ICT) usage affects the bounded rationality and business performance of Small \& Medium Enterprises (SMEs) in Sri Lankan. Data were collected from 400 of SMEs employing structural questionnaire having the face to face interviews. The Partial Least Squares-Structural Equation Modelling (PLS-SEM) was utilized to analyze the data. The results discovered that ICT usage in the organization perfectly makes a significant positive impact on business performance as well as negatively influenced the bounded rationality. Simultaneously, the study uniquely found that bounded rationality makes a negative impact on business performance. Meanwhile, bounded rationality plays a dominant role in the relationship between ICT usage and business performance. The study strongly recommends SMEs to strengthen the usage of ICT especially, mobile technology with applications that play a leading role to develop the SMEs by enhancing the decision-making power.
\end{abstract}

Keywords:- Bounded Rationality, Business Performance, ICT Usage, SMEs

\section{INTRODUCTION}

SMEs are the most important economic entity of any country in either develop or developing. Reasons have been discussed by Prasad, Tata \& Guo (2012), and Priyanath \& Premarathne (2014), said SMEs provide employment opportunities, reducing the poverty, income inequality, and inflation, as well as introducing innovative products, services, and business types for the economy. Nevertheless, some scholars explored that the contribution of SMEs to the GDP has remained below as expected and the failure rate is high (Agwu \& Emeti, 2014; Fatoki, 2011). Less 
performance of these businesses is the significant problem of survival in the market depend on various constraints and challenges (Abor \& Quartey, 2010; Yoshino \& Taghizadeh-Hesary, 2016). One of the major constraints is mostly reflected by the Transaction Cost (TC) (Carmel \& Nicholson, 2005; Priyanath, 2017).

SMEs suffer hazards from opportunism deployed by the exchange partners (Carmel \& Nicholson, 2005; Priyanath, 2017, Priyanath \& Premarathne, 2017c). According to Priyanath (2017), reasons depend on the information asymmetry and further he mentioned the poor capability of access, assess, and handle the information for proper decision making are the issues. In the Transaction Cost Economics (TCE) perspective this incapability of access, assess, and make decisions on the information introduced as the bounded rationality (Williamson, 1981). Therefore, due to the bounded rationality, SMEs have additional costs as search information, negotiation, monitoring transaction activities, and make enforcement to correct the transactions which should additionally pay on avoiding the opportunism and survive in the market (Priyanath, 2017; Priyanath \& Buthsala, 2017; Zhang, 2009).

At present usage of ICT directly associate with using applications that tend to use comprehensive decisionmaking capabilities to SMEs and it increases the business performance (Pham, Le, \& Nguyen, 2013). Organizations can switch their organizational structure from an old more hierarchical inefficient structure to a more flattened efficient structure and it also increases the business performance (Indris, \& Primiana, 2015). Furthermore, ICT infrastructure, especially telecommunication directly creates a path to attend the dynamic marketplace and helps to preserve the competitiveness, improve profitability and success because it disseminates the knowledge among the business partners (Arute \& Gatautis, 2014; Shamsuzzoha, Helo, \& Sandhu, 2017). Therefore, presently, SMEs can adopt such ICT to minimize the bounded rationality and thereby the opportunism and increase their business performance. Although it has been applied to some extent still they incapable to reach the expected level of contribution to the economy (Abor \& Quartey, 2010; Fatoki \& Asah, 2011). Therefore, it is important to examine the impact of bounded rationality on the effect of ICT usage of SMEs for their business performance particularly in Sri Lanka. Thus, the research attempts empirically explore the effect of ICT usage on bounded rationality and business performance particularly SMEs in Sri Lanka and evaluate the mediating effect of bounded rationality on ICT usage and business performance.

The research has developed a distinctive combined model using theoretical bases of ICT usage, bounded rationality, and business performance to understand how ICT usage affects the bounded rationality and business performance in the SME environment which is a unique contribution and has not been 
empirically studied by previous researchers. Consequently, evaluating the mediating effect of bounded rationality in the relationship between ICT usage and business performance also distinctive contribution

\section{THEORETICAL BACKGROUND}

ICT Usage: The world has identified a valuable aspect such as information is the most important aspect which should be considered in all the business functions at the beginning of the information era (James, 2007). Therefore, it has been understood that all the things depend on the information and the literacy of handling such information was very essential for using such information. Thus, the American Library Association (ALA) has defined it as ICT literacy and mentioned four aspects that should be obtained to have such literacy including 1 . The ability to recognize when information is needed; 2 . The ability to locate the needed information; 3 . The ability to evaluate the suitability of retrieved information, and 4 . The ability to use effectively and appropriately the needed information (American Library Association (ALA) 1989). While the technology was progressively improving in the world the scope of the operationalization of ICT literacy also changed. Glister (1997: P. 01) provided a general explanation of ICT literacy as "Digital Literacy" and which explained it as "an ability to understand and to use information from a variety of digital sources" as well as he mentioned that "mastering ideas, not keystrokes". Therefore, it is not only the familiarity but also practical use.

Digitally literate people are fastmoving entities from one kind of medium to another kind and find out best fit knowledge through the information to become skilled people and represent knowledge to the audience in the easiest way to understand (Lankshear \& Knobel, 2003). Simultaneously, Lennon, et al. (2003: P. 08) mentioned "the interest, attitude, and ability of individuals to appropriately use digital technology and communication tools to access, manage, integrate, and evaluate information; construct new knowledge, and communicate with others to participate effectively in society". According to the above definitions, ICT usage may in beyond ICT literacy or digital literacy. It can be extricated that the ICT implementation and the practical use of its various dimensions should be considered while experimenting with the ICT usage of an organization. Most of the researchers who are concerned about ICT literacy or digital literacy have studied the ICT usage of the organization (Esselaar, et al., 2007).

Bounded Rationality: The logic of price mechanism and the perfectly competitive market emphasized by the classical economists had been criticized by the Coase (1937) and explained it does not exist in the real world and exchange partners pay costs to eliminate the imperfection because of imperfection due to the information asymmetry. Humans are bounded rational due to the incapability of handling information 
(Simon, 1990). According to his generalization, this limitation is two folds. The former is cognitive attributes and the latter is language processing limitations. Therefore, due to information asymmetry or the incapability of processing information always makes benefit to one party than the other party, and hence, opportunism is elevated in the market (Williamson, 1981). Therefore, the barriers in collecting, processing, and assessing information for making the proper decision affecting the business introduced as the bounded rationality (Priyanath \& Buthsala, 2017; Zhang, 2009).

These constraints of access, assess, and decision-making on the information makes the opportunity for one transaction partner to hide the actual situation and generate fear in the opposite partner (Gigerenzer \& Goldstein, 1996; Nguyen \& Crase, 2011). Economizing this gap called bounded rationality takes two forms: Former concerns decision processes, and the latter involves governance structures, and thus it increases the cost for the one partner. TCE is principally concerned with the economizing consequences of assigning transactions as opposed to the realities of bounded rationality, the costs of planning, adapting, and monitoring transactions need to be considered (Williamson, 1985).

Business Performance: According to Bourne et al. 2003, and Khare, Saxsena, \& Teewari, 2012, the performance is a value of the outcome which is evaluated on a particular type of standard or benchmark. In the SME context, the performance was defined by Nieman, Hough \& Nieuwenhuizen (2003) said if the business survives more than two years having a staff of more than five and less than thirty by earning profit as well as expand the business in terms of infrastructure and growth can be the success. The success of the SME frequently depends on growth or profitability. Growth could be measured in terms of turnover, employment levels, or as the percentage change in sales over a year, investment plans, and expected achievements, all of which can be calculated quantitatively (Simpson, Taylor \& Barker, 2004; Yazdanfar \& Öhman, 2014).

However, the selection of the evaluation measurements is a more difficult task and hence, a heavy foundation of the best measurements cannot be found (Richard, Devinney, Yip, \& Johnson, 2009). Frequently, most researchers used only the financial measures for estimating the performance. Nevertheless, some recent studies mostly rely on the relevance of non-financial perspectives such as stakeholder satisfaction, employee growth, skill improvement, flexible lifestyle, business survival, customer satisfaction, customer retention, and career progress (O'Regan \& Ghobadian, 2004; Walker \& Brown, 2016).

Some researchers argued that concentrating in the narrow range of measures obtain inappropriate result about the success of an organization and therefore, it should be used multiple types of measures which provide significant explanatory power 
to predict the business achievements (Haber \& Reichel, 2005; Simpson et al., 2004). Garengo, Biazzo, \& Bititci (2005) has also mentioned performance measurement systems play an important role in SME's development. A researcher who conducted researches on measuring the performance of SMEs particularly made more attention to overall performance rather than the traditional measures of only using financial performance (Saunila, 2016; Waśniewski, 2017). Two types of performance were identified by Santos \& Brito, (2012) such as financial performance and strategic performance instead of standard operational performance. Waśniewski (2017) proposed another system for measuring the performance of SMEs which depended on the key success factors of the organization. Thereby, including all the consideration this research uses not only the strategic factors but also the operational factors to evaluate SME business performance (Santos \& Brito, 2012; Tarute \& Gatautis, 2014).

\section{RESEARCH MODEL AND HYPOTHESES}

Although the major objective is to achieve the expected higher performance level SMEs fail to reach it due to the situation of imperfect behavior of the market (Carmel \& Nicholson, 2005; Dyer \& Chu, 2003; Nooteboom 1993; Priyanath, 2017). Priyanath (2017), Priyanath \& Premaratne (2017a, 2017b) stated that opportunism is the issue that incurred the TC and thereby low performance. Opportunism arose due to the bounded rationality (Zhang, 2009). Bounded rationality of the decisionmakers identified as the incapability of access, assess, evaluating, and make decisions on the business functions. Therefore, providing such adequate, reliable, and timely information to the SMEs reduces the bounded rationality and thereby increase the performance because it minimizes the opportunism as well as the TC. The major responsibility of ICT is to provide the abovementioned adequate, reliable, and timely information for facilitating access, assess, and decision making (James, 2007; Kenneth \& Jane, 2013). Therefore, certainly, ICT reduces the bounded rationality and increase the business performance of SMEs. Thus, how the mediating effect of bounded rationality. Figure 01 conceptually established this rationale.

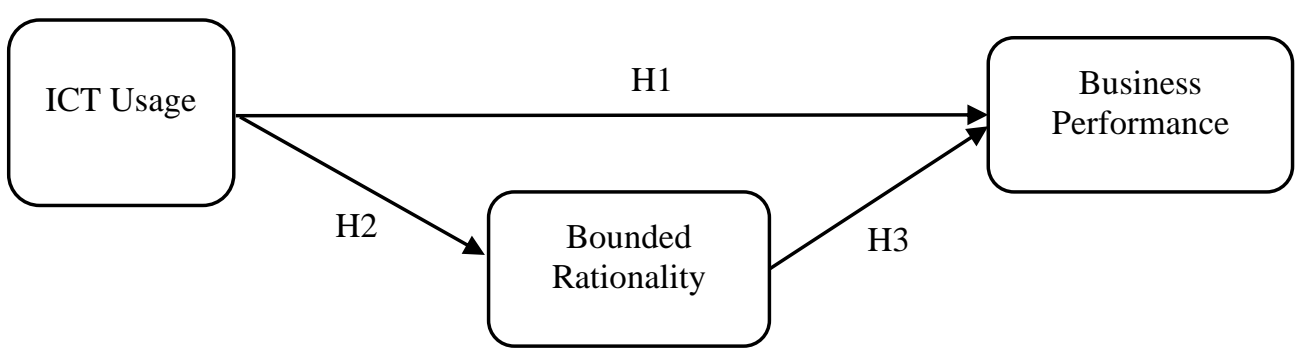

Figure 1: Relationships among ICT, bounded rationality and business performance of SME 
ICT usage and business performance: ICT usage is been applied to minimize market imperfection by providing proper information flows among the business partners and can eliminate the interdependencies among the related factors which are contributing to the growth of the business (Cordella, 2006). ICT usage, such as telephones, mobile devices, communication networks, and electronic data transferring facilities enhance the access, assess including management of information as a valuable resource and produce required appropriate knowledge and enhance the rationality of the people to make the proper decision in the collaborative environment which directly cause to minimize the market barriers by reducing the TC as well as increase the business performance (Karim et al., 2018; Kenneth \& Jane, 2013; Wambaria, Kibas, \& Asienga, 2016). Besides, these infrastructure capabilities improve the quality of services which mainly focused on external communication with other organizations and customers easily. Therefore, according to Nooteboom (1993), organizations attempt on more

outsourcing and mitigate the transaction cost since the use of ICT. ICT is the way of assembling the requirements of corporate

entrepreneurship which is needed by firms to accomplish higher productivity, efficiency, and performance in the rapidly changing knowledge economy (Kuratko \& Audretsch, 2013). The ICT reduces the time gap between product idea and manufacturing as well as product manufacturing to customer delivery while employing fewer employees and hence, the business can attain good performance (Kathleen \& Wilburn, 2018). Conversely, according to Consoli (2012), he mentioned that the ICT infrastructure directly affects the economic growth of an organization. Therefore, the study predicts the following hypothesis;

\section{H1: ICT usage positively relates to the business performance of SMEs}

ICT usage and bounded rationality: ICT engage all stakeholders who involve from the supply of raw materials for manufacturing to delivery of the finished product to the customer together by applying various infrastructure and applications and therefore, a communication gap between these parties does not exists (Kathleen \& Wilburn, 2018). These adequate, reliable, and timely information increase the rationality by providing easy access to the information, methods for assessing information easily by the applications and finally make proper decisions on that information which leads to reduce the bounded rationality (Cordella, 2006; Zhang, 2009) Furthermore, Markus \& Thamos (2002) stressed that the digital networks mitigate the bounded rationality. Thus, the ICT usage facilitates access and assess information which directly affects to minimize the bounded rationality of the decision-makers. Therefore, the following hypotheses are developed: 
H2: ICT usage negatively relates to the bounded rationality of SMES

\section{Bounded Rationality and business performance: \\ Opportunistic}

behavior of the business partners generated by several factors and bounded rationality is one leading factor (Williamson, 1985). Therefore, a less rational person makes fear for transactions and use extra methods to minimize it and these safeguarding attempts generate more cost on searching information, negotiation, monitoring, and enforcement on the transactions (Dyre \& Chu, 2003; Hobbs, 1996; Priyanath \& Premarathne, 2017; Priyanath \& Buthsala, 2017). Finally, this extra cost reduces business performance (Priyanath \& Premarathne 2017). Therefore, the following proposition is been made by the study:

\section{H3: Bounded rationality negatively relates to the business performance of SMEs.}

\section{ICT usage bounded rationality and} business performance: the consistency on methods of the transaction between both suppliers to business and business to customer in the newest technologies has been increased and therefore it improves the performance of the business organizations (Mingle \& Dzandu, 2013). Consoli (2012) conducted a literature analysis of ICT impact on companies and identified significant positive effects into 4 groups such as performance, growth, expansion, and new products and some other studies found ICT investment as the policy may affect considerably on both productivity and the economic growth of an organization (Sabbagh et al., 2012). According to the establishment of hypothesis H2, ICT usage reduces the bounded rationality, and consequently, bounded rationality reduces the business performance as mentioned in hypothesis H3. Therefore, the study predicts that:

\section{H15: Bounded rationality has a mediating role in the relationship between ICT usage and business performance of SMEs}

\section{METHODS}

As mentioned in the theoretical framework three pieces of theories combined for addressing the research problem and therefore, use the deductive approach, and the method is quantitative. The study selected only the manufacturing SMEs and the survey method is used for the data collection on a unit of analysis as the SME owners. Department of Census and Statistics (DCS) has defined for SMEs as $5-24$ persons engaged for small industries and 25 - 199 persons engaged for medium enterprises. It is used as the study population and the quantity is value is 81,531 SMEs. 400 of SMEs are selected employing the 'Inverse Square Root Method' of minimum sample size determination formula for the Partial Least Square Structural Equation Modelling (PLSSEM) after conducting the pilot survey and analysis of 110 SMEs (Kock \& Hadaya, 2018; Ranatunga, Priyanath \& Meegama, 2020). The sample populated according to the percentage share of the SMEs distribution in each district and determine the number of SMEs to 
represent all the districts in Sri Lanka. A stratified sampling method was utilized to select items representing all the manufacturing industrial divisions categorized in the ISIC category.

The 7-point Likert scale questionnaire is prepared on a twostep procedure including identifying the pool of items for each variable by reviewing the past literature and select items carefully according to the environment of Sri Lanka. Therefore, the items of the questionnaire were systematically designed according to the literature published in cited journals. In order to protect the validity and reliability of the study, the questionnaire has been pre-tested by using a pilot survey before the main survey and it is verified whether the questions are understood; whether the instructions are cleared; whether the order of the questions is appropriate and the questions are useful, etc. Face-to-face interviews were conducted with owners/managers of SMEs to collect data. PLS-SEM is identified as the most useful analysis technique for multiple independent and dependent variables. The study used this technique and the reliability and validity tests and the efficiency of the model have been examined by multicollinearity issues, R2, effect size (f2), and predictive relevance (Q2). The SmartPLS (version 2) software is used to analyze data.

Measures: ICT usage considered as a wide range of attributes such as implemented ICT infrastructure, used ICT applications, established organization's ICT policy, available
ICT skilled human resources, and used mobile technology (Giotopoulos, et al., 2017; Mithas, Tafti, Bardhan, \& Goh, 2012; Pham, 2010; Pham et al., 2013). According to Pham (2010) and Pham et al. (2013) 10 items were used to measure the infrastructure and another 10 items used to measure applications while 06 items are being used for measuring the policy and 04 items to measure skilled human resources. Another 10 items have been utilized to operationalize the used mobile technology. According to Priyanath (2017), three major attributes of bounded rationality have been identified. Measure the limitation of access to the information, identify the limitations of assessing information, and evaluate the difficulty of making good decisions on the obtained information.

Because bounded rationality mainly focused on the information asymmetry as well as the incapability of processing information, the level of access, and assessing information of the SMEs give a good evaluation of their bounded rationality. Therefore, the study employed 1) Explore the ability to find information on the market, suppliers, and buyers on the accessing information by using 08 items, 2) information evaluating capability on each of market, supplier, and the buyer under the assessing information by using another 04 items and finally, 3 ) consider the capability of handling consequences which come from the market, suppliers, and buyers under the capability of making good decisions on such information by using another 04 items in order to 
operationalize the bounded rationality. Two variations of performance measures are been practically identified as appropriate to this study such as financial and operational performance (Liang, Huang, Yeh, \& Lin, 2010; Santos \& Brito, 2012; Tarutè, \& Gatautis, 2014). The financial performance measured as profitability, growth, market value, and conversely, strategic or operational performance indicated by customer satisfaction, employee satisfaction, environmental performance, and social performance. Cover the financial performance, profitability operationalizes by 05 items and the growth operationalizes by using another 05 items. Consequently, within the strategic or operational performance, customer satisfaction operationalizes by 07 items, employee satisfaction operationalizes by 05 items, environmental performance operationalizes by 04 items and social performance operationalize by another 02 items.

\section{RESULTS}

The measurement model was first analyzed by examining the reliability and validity of the seven first-order constructs as shown in table 1 (Hair, Sarstedt, Ringle, \& Mena, 2012; Robson, 2002; Thatcher, 2010). According to table 1 the indicator reliability examined by the factor lodgings and all factor loading are above the threshold value 0.7 in the statistical significance at 0.05 level. The measures of Cronbach's $\alpha$ and composite reliability of seven constructs also shown in table 1 are above the threshold value 0.7 and hence the first-order constructs well above indication high reliability. Consequently, two validity tests such as convergent validity and the discriminant validity have been evaluated on the seven first-order constructs. All average variance extracted (AVE) values exceeded the required 0.5 thresholds and reached to the convergent validity and indicators reflect their latent constructs. Finally, discriminant validity (see table 2) is supported as the average shared variance of a construct and its indicators (diagonal values that are indicated by bold letters of the square root of AVE values) exceed the shared variance with other constructs (Fornell \& Larcker,

1981).

Table 1: Analysis of First-Order Constructs

\begin{tabular}{|c|c|c|c|c|c|c|}
\hline \multicolumn{2}{|r|}{ Construct } & Loading & t- & $\mathbf{C R}$ & AVE & $\boldsymbol{\alpha}^{*}$ \\
\hline \multirow[t]{5}{*}{1} & \multicolumn{3}{|c|}{ Business Performance Customer Satisfaction } & \multirow[t]{5}{*}{0.971} & \multirow[t]{5}{*}{0.828} & \multirow[t]{5}{*}{0.965} \\
\hline & Customer feedback on our production & 0.937 & 57.091 & & & \\
\hline & $\begin{array}{l}\text { Changes of production according to the } \\
\text { customer feedback }\end{array}$ & 0.920 & 41.554 & & & \\
\hline & $\begin{array}{l}\text { Introduce new production according to } \\
\text { the customer requests }\end{array}$ & 0.905 & 34.066 & & & \\
\hline & Growth of Number of customers in each & 0.888 & 41.952 & & & \\
\hline
\end{tabular}


Ranatunga R.V.S.P.K., Priyanath H.M.S., Megama R.G.N., Wayamba Journal of Management $11(2)$

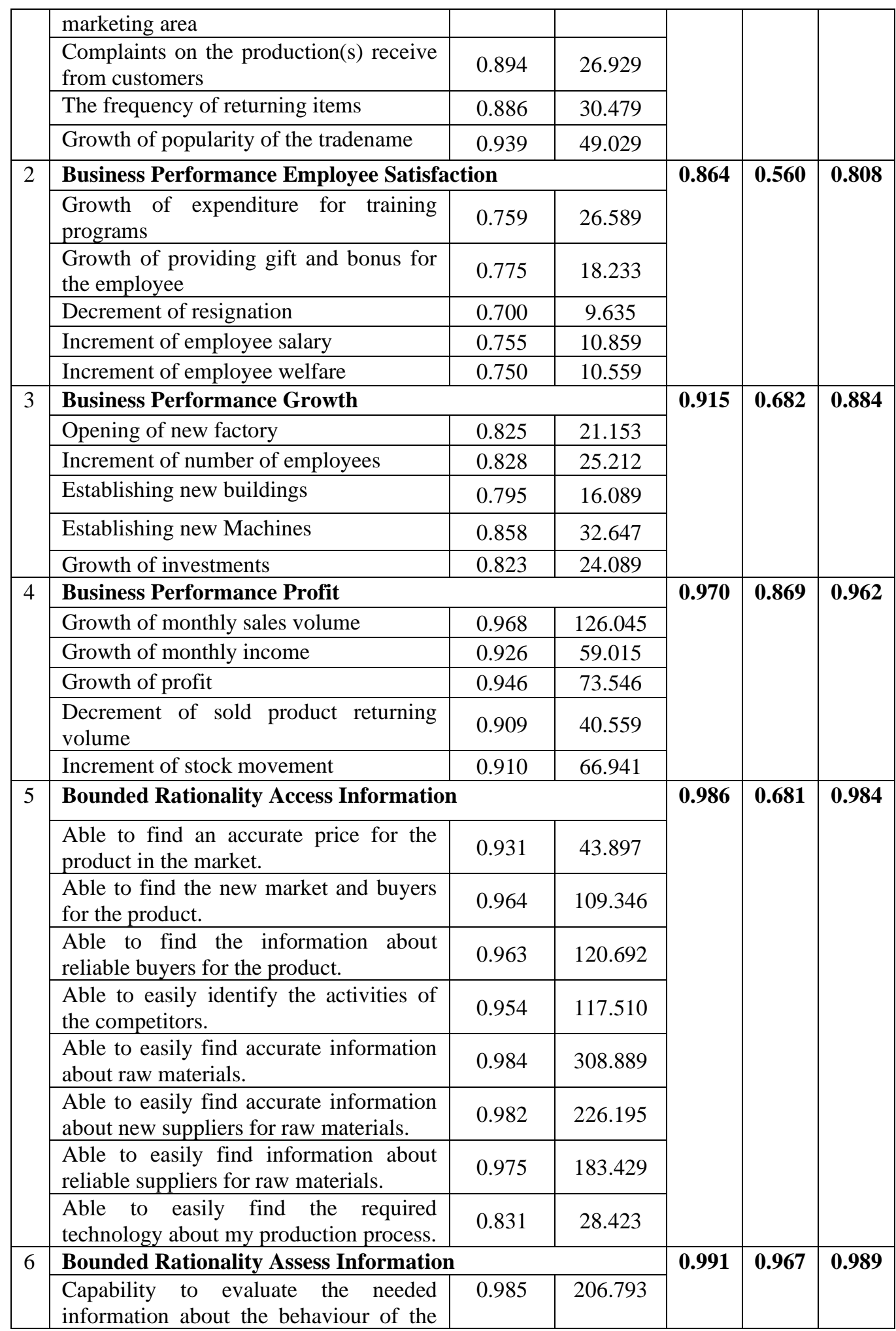


Ranatunga R.V.S.P.K., Priyanath H.M.S., Megama R.G.N., Wayamba Journal of Management $11(2)$

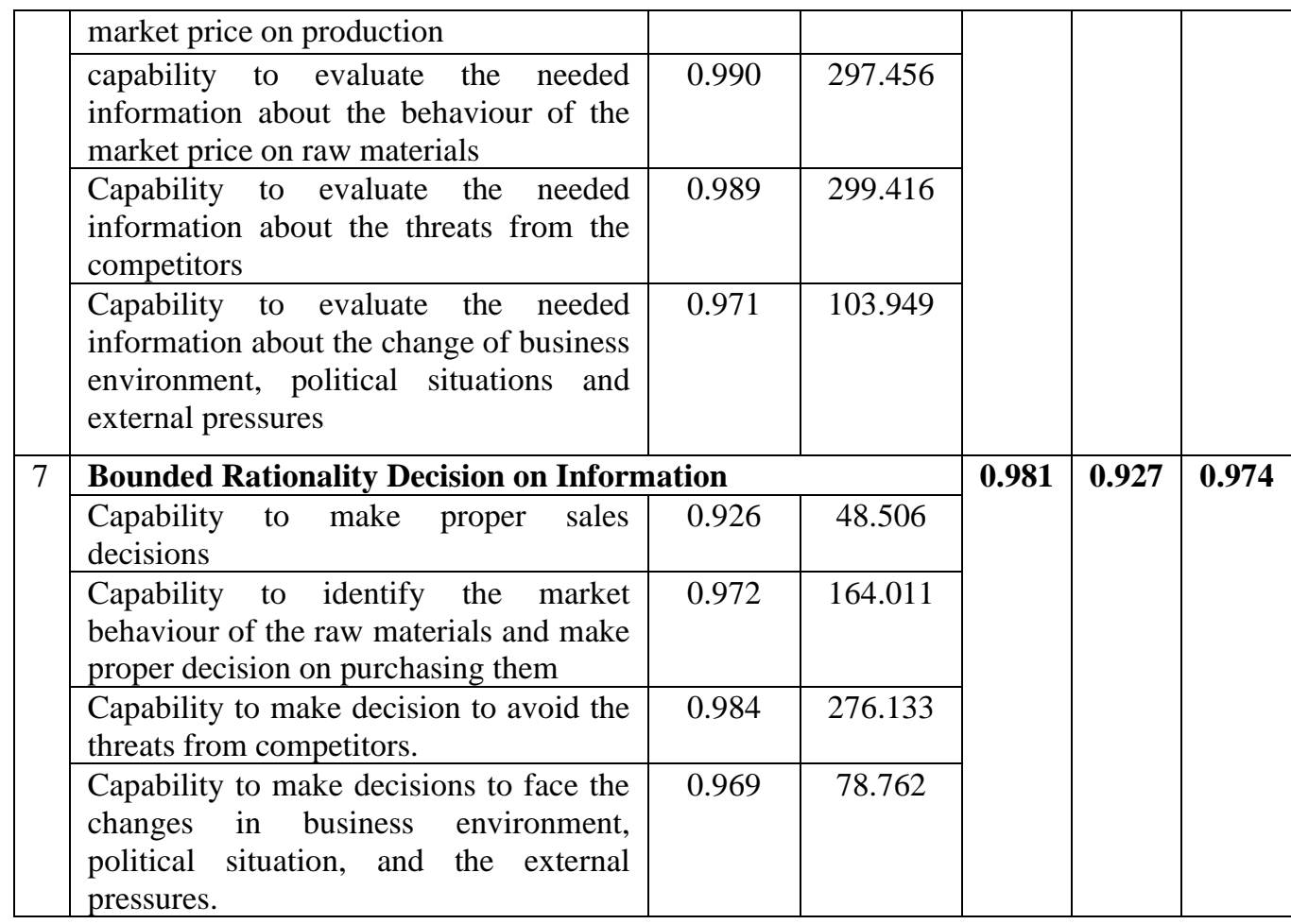

$(n=400)$,

Source: Survey data, 2020

Table 2: Discriminant Validity of First-Order Constructs

\begin{tabular}{|l|l|c|c|c|c|c|c|c|}
\hline & & $\mathbf{1}$ & $\mathbf{2}$ & $\mathbf{3}$ & $\mathbf{4}$ & $\mathbf{5}$ & $\mathbf{6}$ & $\mathbf{7}$ \\
\hline $\mathbf{1}$ & $\begin{array}{l}\text { BPF } \\
\text { Growth }\end{array}$ & $\mathbf{0 . 8 2 6}$ & & & & & & \\
\hline $\mathbf{2}$ & BPF Profit & 0.813 & $\mathbf{0 . 9 3 2}$ & & & & & \\
\hline $\mathbf{3}$ & BPO Cus & 0.810 & 0.904 & $\mathbf{0 . 9 1 0}$ & & & & \\
\hline $\mathbf{4}$ & BPO_EMP & 0.641 & 0.615 & 0.621 & $\mathbf{0 . 7 4 8}$ & & & \\
\hline $\mathbf{5}$ & Access & -0.533 & -0.652 & -0.648 & -0.360 & $\mathbf{0 . 8 2 5}$ & & \\
\hline $\mathbf{6}$ & Assess & -0.557 & -0.667 & -0.643 & -0.348 & 0.802 & $\mathbf{0 . 9 8 3}$ & \\
\hline $\mathbf{7}$ & Decision & -0.510 & -0.625 & -0.603 & -0.329 & 0.852 & 0.960 & $\mathbf{0 . 9 6 3}$ \\
\hline
\end{tabular}

$(\mathrm{n}=400)$,

Source: Survey data, 2020

The second-order constructs are been established by using the latent variable scores of the first-order constructs. The table 3 indicated that the seven endogenous latent variables such as business performance (BP), Bounded Rationality (BR), ICT Applications (ICT APP), ICT Human Resources (ICT HR), ICT Mobile technology (ICT MT), ICT Policy 
(ICT Policy), and ICT Infrastructure (ICT INF) established under the second-order level in order to evaluate the hierarchical model. As discussed in the first-order model evaluation the second-order model also has been tested for reliability and validity. All the factor loadings, Cronbach's $\alpha$, and composite reliability exceed the threshold value of 0.7 at the significance level 0.05 , and hence, the constructs obtain the reliability. The AVE values of the constructs are above 0.5 and according to table 4 the square root of $\mathrm{AVE}$ values in the diagonal exceed the shared variance and both of the convergent and the discriminant validity of the constructs received and satisfied.

Table 3: Analysis of Second-Order Constructs

\begin{tabular}{|c|c|c|c|c|c|c|}
\hline \multicolumn{2}{|r|}{ Construct } & Loading & t- & $\mathbf{C R}$ & AVE & $\boldsymbol{\alpha}^{*}$ \\
\hline \multirow[t]{8}{*}{1} & \multicolumn{3}{|l|}{ Business Performance } & \multirow{8}{*}{0.942} & \multirow{8}{*}{0.700} & \multirow{8}{*}{0.928} \\
\hline & Profit & 0.805 & 17.389 & & & \\
\hline & Growth & 0.880 & 31.392 & & & \\
\hline & Employee satisfaction & 0.920 & 76.508 & & & \\
\hline & Customer satisfaction & 0.921 & 76.113 & & & \\
\hline & Policy on environmental protection & 0.757 & 16.503 & & & \\
\hline & $\begin{array}{l}\text { Allocation of job opportunities for } \\
\text { employees who represent less } \\
\text { income group }\end{array}$ & 0.757 & 14.994 & & & \\
\hline & $\begin{array}{l}\text { Conducting social activities such as } \\
\text { help to disabilities, cultural events } \\
\text { etc. }\end{array}$ & 0.796 & 20.453 & & & \\
\hline \multirow[t]{4}{*}{2} & \multicolumn{3}{|l|}{ Bounded Rationality } & \multirow{4}{*}{0.994} & \multirow{4}{*}{0.981} & \multirow{4}{*}{0.990} \\
\hline & Access to the information & 0.931 & 392.167 & & & \\
\hline & Assess the information & 0.964 & 541.726 & & & \\
\hline & Make decisions on information & 0.963 & 421.832 & & & \\
\hline \multirow[t]{6}{*}{3} & \multicolumn{3}{|l|}{ ICT Usage Infrastructure } & \multirow{6}{*}{0.905} & \multirow{6}{*}{0.659} & \multirow{6}{*}{0.869} \\
\hline & $\begin{array}{l}\text { Use fixed line telephone for } \\
\text { business purposes. }\end{array}$ & 0.749 & 13.504 & & & \\
\hline & $\begin{array}{l}\text { Use computers for business } \\
\text { purposes. }\end{array}$ & 0.912 & 51.118 & & & \\
\hline & Use local area network & 0.915 & 54.381 & & & \\
\hline & $\begin{array}{l}\text { Has Broadband internet access and } \\
\text { Wifi }\end{array}$ & 0.756 & 14.478 & & & \\
\hline & $\begin{array}{l}\text { Use other peripherals like POS, } \\
\text { barcode readers, fax machines, } \\
\text { photocopy/scanner machines etc. }\end{array}$ & 0.704 & 11.733 & & & \\
\hline \multirow[t]{2}{*}{4} & \multicolumn{3}{|l|}{ ICT Usage Applications } & \multirow[b]{2}{*}{0.919} & \multirow[b]{2}{*}{0.620} & \multirow[b]{2}{*}{0.898} \\
\hline & $\begin{array}{l}\text { Handle business activities using } \\
\text { standard applications such as MS } \\
\text { office with the computers }\end{array}$ & 0.743 & 17.700 & & & \\
\hline
\end{tabular}


Ranatunga R.V.S.P.K., Priyanath H.M.S., Megama R.G.N., Wayamba Journal of Management $11(2)$

\begin{tabular}{|c|c|c|c|c|c|c|}
\hline \multirow{6}{*}{ 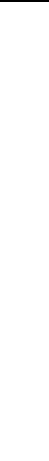 } & $\begin{array}{l}\text { Use customized software for } \\
\text { handling business functions }\end{array}$ & 0.798 & 24.848 & & & \\
\hline & $\begin{array}{l}\text { Use Management Information } \\
\text { Systems }\end{array}$ & 0.806 & 19.903 & & & \\
\hline & $\begin{array}{l}\text { Use Databases and knowledge } \\
\text { bases }\end{array}$ & 0.862 & 32.195 & & & \\
\hline & Organization has e-Mail address & 0.752 & 12.706 & & & \\
\hline & $\begin{array}{l}\text { Use social media like Facebook for } \\
\text { business purposes }\end{array}$ & 0.778 & 13.691 & & & \\
\hline & $\begin{array}{l}\text { Use } \quad \text { e-Banking/e-money } \\
\text { applications for business purposes }\end{array}$ & 0.766 & 14.988 & & & \\
\hline \multirow[t]{7}{*}{5} & \multicolumn{3}{|l|}{ ICT Usage Policy } & \multirow{7}{*}{0.983} & \multirow{7}{*}{0.908} & \multirow{7}{*}{0.980} \\
\hline & Investment for ICT development & 0.966 & 107.031 & & & \\
\hline & $\begin{array}{l}\text { Assess the ICT infrastructure on } \\
\text { regular time }\end{array}$ & 0.956 & 52.864 & & & \\
\hline & Security policy & 0.943 & 62.290 & & & \\
\hline & Followed rules and regulations & 0.950 & 61.396 & & & \\
\hline & Employee training as a policy & 0.941 & 48.144 & & & \\
\hline & $\begin{array}{l}\text { Updating software and hardware as } \\
\text { a policy }\end{array}$ & 0.961 & 89.371 & & & \\
\hline 6 & \multicolumn{3}{|l|}{ ICT Usage Human Resources } & \multirow{6}{*}{0.872} & \multirow{6}{*}{0.578} & \multirow{6}{*}{0.822} \\
\hline & Employees have IT knowledge & 0.731 & 13.045 & & & \\
\hline & Recruiting specialized IT persons & 0.802 & 19.190 & & & \\
\hline & $\begin{array}{l}\text { Employees can use computers and } \\
\text { related equipment's }\end{array}$ & 0.814 & 17.127 & & & \\
\hline & $\begin{array}{l}\text { Employees use Internet Messaging } \\
\text { or e-mails }\end{array}$ & 0.717 & 12.293 & & & \\
\hline & Decision making using MIS & 0.734 & 12.832 & & & \\
\hline \multirow[t]{8}{*}{7} & \multicolumn{3}{|l|}{ ICT Usage Mobile Technology } & \multirow{8}{*}{0.958} & \multirow{8}{*}{0.718} & \multirow{8}{*}{0.950} \\
\hline & Use of mobile phones & 0.852 & 25.683 & & & \\
\hline & $\begin{array}{l}\text { Use of mobile equipment with } \\
\text { internet connection for business } \\
\text { purposes }\end{array}$ & 0.867 & 28.411 & & & \\
\hline & $\begin{array}{l}\text { Use of mobile applications for } \\
\text { communications } \\
\text { WhatsApp, Imo) }\end{array}$ & 0.867 & 27.954 & & & \\
\hline & $\begin{array}{l}\text { Use of social media through mobile } \\
\text { connection(Facebook, LinkedIn) }\end{array}$ & 0.883 & 34.441 & & & \\
\hline & $\begin{array}{l}\text { Employees use internet massaging } \\
\text { or email through mobile phones for } \\
\text { business purposes }\end{array}$ & 0.736 & 17.133 & & & \\
\hline & $\begin{array}{l}\text { Generally, employees use internet } \\
\text { and its services through mobile } \\
\text { phones for business purposes }\end{array}$ & 0.850 & 27.536 & & & \\
\hline & $\begin{array}{l}\begin{array}{l}\text { Generally, employees do video } \\
\text { conferencing through }\end{array} \text { mobile } \\
\end{array}$ & 0.848 & 29.956 & & & \\
\hline
\end{tabular}




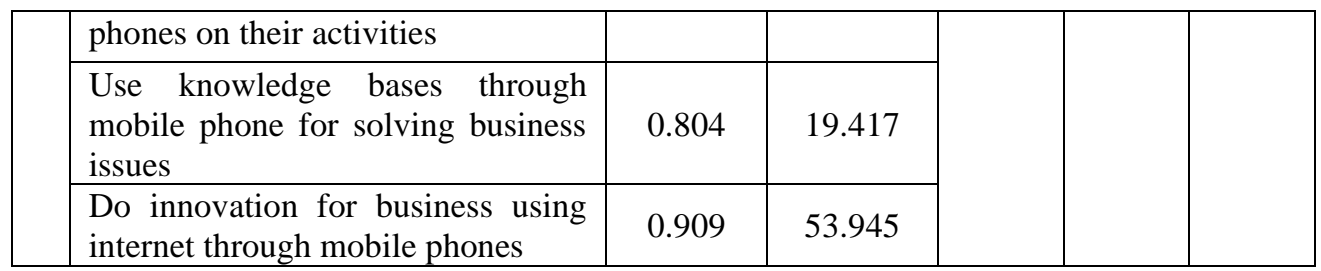

$(\mathrm{n}=400)$,

Source: Survey data, 2020

Table 4: Discriminant Validity of Second-Order Constructs

\begin{tabular}{|l|l|c|c|c|c|c|c|c|}
\hline & & $\mathbf{1}$ & $\mathbf{2}$ & $\mathbf{3}$ & $\mathbf{4}$ & $\mathbf{5}$ & $\mathbf{6}$ & $\mathbf{7}$ \\
\hline $\mathbf{1}$ & BP & $\mathbf{0 . 8 3 7}$ & & & & & & \\
\hline $\mathbf{2}$ & BR & -0.624 & $\mathbf{0 . 9 9 0}$ & & & & & \\
\hline $\mathbf{3}$ & ICT App & 0.711 & -0.501 & $\mathbf{0 . 7 8 7}$ & & & & \\
\hline $\mathbf{4}$ & ICT HR & 0.770 & -0.523 & 0.735 & $\mathbf{0 . 7 6 0}$ & & & \\
\hline $\mathbf{5}$ & ICT MT & 0.750 & -0.594 & 0.584 & 0.757 & $\mathbf{0 . 8 4 8}$ & & \\
\hline $\mathbf{6}$ & ICT Pol & 0.706 & -0.476 & 0.721 & 0.725 & 0.558 & $\mathbf{0 . 9 5 3}$ & \\
\hline $\mathbf{7}$ & ICT Inf & 0.721 & -0.584 & 0.761 & 0.692 & 0.660 & 0.665 & $\mathbf{0 . 8 1 2}$ \\
\hline
\end{tabular}

$(\mathrm{n}=400)$,

Source: Survey data, 2020

The latent variable scores of secondorder constructs are used to establish the third-order constructs. Table 5 indicated that the three endogenous latent variables such as business performance (BP), Bounded Rationality (BR), and ICT usage established under the third-order level in order to evaluate the hierarchical model. As discussed above the thirdorder model also has been tested for reliability and validity. All the factor loadings, Cronbach's $\alpha$, and composite reliability exceed the threshold value of 0.7 at the significance level 0.05 , and hence, the constructs obtain the reliability. The AVE values of the constructs are above 0.5 and according to table 6 the square root of AVE values in the diagonal exceed the shared variance and these measures give the convergent and discriminant validity to the constructs.

Table 5: Analysis of Third-Order Constructs

\begin{tabular}{|c|l|c|c|c|c|c|}
\hline \multicolumn{2}{|c|}{ Construct } & Loading & $\begin{array}{c}\text { t- } \\
\text { Statistics }\end{array}$ & CR & AVE & $\boldsymbol{\alpha}^{*}$ \\
\hline \multirow{2}{*}{1} & Business Performance & & & \\
\cline { 2 - 4 } & Growth & 0.894 & 20.321 & \multirow{3}{*}{$\mathbf{0 . 9 3 8}$} & \multirow{2}{*}{$\mathbf{0 . 7 1 6}$} & \multirow{2}{*}{$\mathbf{0 . 9 2 0}$} \\
\cline { 2 - 4 } & Profit & 0.921 & 20.433 & & & \\
\cline { 2 - 4 } & Customer satisfaction & 0.914 & 21.256 & & & \\
\hline
\end{tabular}




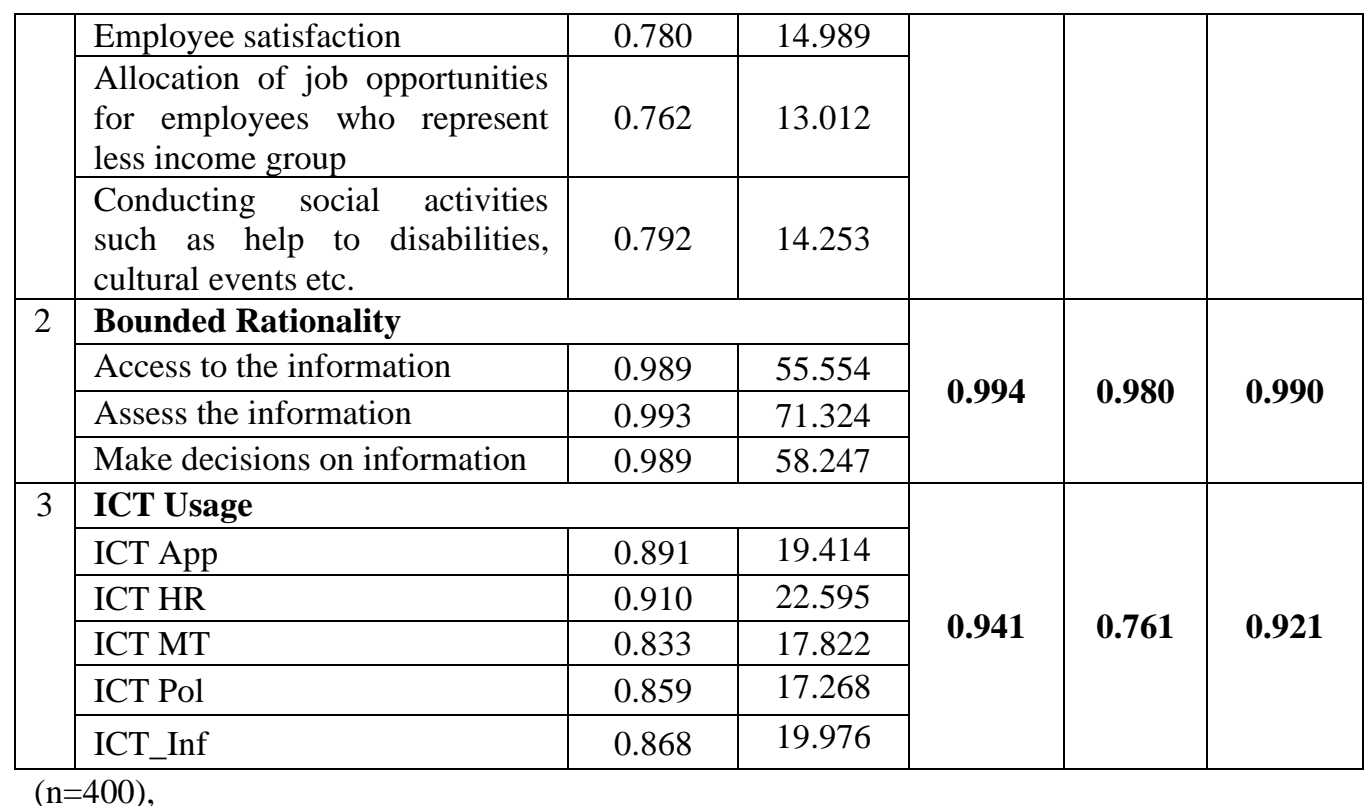

Source: Survey data, 2020

Table 6: Discriminant Validity of Third-Order Constructs

\begin{tabular}{|c|c|c|c|c|}
\hline & & 1 & 2 & 2 \\
\hline 1 & BP & 0.846 & & \\
\hline 2 & BR & -0.610 & 0.990 & \\
\hline 3 & ICT Usage & 0.746 & -0.613 & 0.872 \\
\hline
\end{tabular}

$(\mathrm{n}=400)$,

Source: Survey data, 2020

Finally, the inner model has been assessed according to the given guidance by Hair, Hult, Ringle, \& Sarstedt (2014). Initially, collinearity issues have been examined. According to both VIF values obtained 1.525, and hence the analysis does not depict any collinearity issues since VIF values are lower than the threshold 5. As well as the tolerance levels are in 6.56 which exceeded the threshold value of 0.2 . Therefore, the structural model does not contain any multicollinearity issues between the independent constructs and the dependent constructs.

The next step assessed the significance of the path coefficients using $\beta$ value and t-statistics to identify the effect of ICT usage on the bounded rationality and the business performance of the SMEs by using the PLS bootstrap process. The path coefficients as depicted in table 01 ICT usage has a significant positive effect on business performance including $\beta=0.760$ and t-statistics 11.821. As well as ICT 
usage has a significant negative relationship on the bounded rationality as $\beta=-0.616$ and $\mathrm{t}$ statistics 10.326. Finally, table 7 shows that the bounded rationality has a negative relationship on the business performance with $\beta=-0.147$ and t-statistics .801. Therefore, H1, $\mathrm{H} 2$, and $\mathrm{H} 3$ hypotheses have been accepted.

Table 7: Path Coefficient and Significance

\begin{tabular}{|c|l|c|c|c|}
\hline Hypotheses & \multicolumn{1}{|c|}{ Relationship } & Beta (Path) & $\begin{array}{c}\text { T } \\
\text { Statistics }\end{array}$ & Decision \\
\hline H1 & ICT Usage -> BP & $0.760^{* * *}$ & 11.821 & Accept \\
\hline H2 & ICT Usage -> BR & $-0.616^{* * *}$ & 10.326 & Accept \\
\hline H3 & BR -> BP & $-0.147 *$ & 1.801 & Accept \\
\hline
\end{tabular}

$* \mathrm{P}>0.1, * * \mathrm{P}>0.05, * * * \mathrm{P}>0.01,(\mathrm{n}=400)$,

$\mathrm{R}^{2}=0.736(\mathrm{BP}), 0.380(\mathrm{BR})$

$\mathrm{Q}^{2}=0.763(\mathrm{BP}), 0.891(\mathrm{BR})$

Source: Survey data, 2020

This study concerned the mediate effect of bounded rationality on the relationship between ICT usage and the SME business performance under the $\mathrm{H} 4$ and this kind of relationship have not been empirically studied in the literature. According to instructions given by Zhao, Lynch \&
Chen (2010) and Carrión, Nitzl, \& Roldán, (2017), Table 08 shows the analysis of the mediate effect of BR and it depicts complementary mediate effect (VAE value is 0.106 ) between ICT usage and business performance of SMEs in Sri Lanka and the H4 is been accepted.

Table 8: Analysis of the mediate effect of bounded rationality on ICT usage and business performance of SMEs

\begin{tabular}{|c|c|c|c|c|c|c|c|c|}
\hline \multirow[b]{2}{*}{ Path } & \multicolumn{2}{|c|}{$\begin{array}{c}\text { Direct effect } \\
\text { model }\end{array}$} & \multirow{2}{*}{$\begin{array}{r}\begin{array}{r}\text { Indirec } \\
\text { t effect }^{\mathrm{c}}\end{array} \\
a x b\end{array}$} & \multirow{2}{*}{$\begin{array}{l}\mathbf{S e}^{\mathrm{d}} \\
(\mathrm{SD})\end{array}$} & \multirow{2}{*}{$\frac{\mathrm{t}_{\text {-stat }}}{(a x b) / \mathrm{S}_{\mathrm{e}}}$} & \multirow{2}{*}{$\begin{array}{c}\begin{array}{c}\text { Total } \\
\text { effect }^{\mathrm{f}}\end{array} \\
(a x b) \\
+\mathrm{c}\end{array}$} & \multirow{2}{*}{$\begin{array}{c}\text { VAF } \\
\mathbf{a x b /} \\
(\mathbf{a x b})+\mathbf{c}\end{array}$} & \multirow{2}{*}{$\begin{array}{c}\text { Type of } \\
\text { the } \\
\text { mediation }\end{array}$} \\
\hline & $\boldsymbol{\beta}^{\mathrm{a}}$ & $\begin{array}{c}\text { t- } \\
\text { stat }\end{array}$ & & & & & & \\
\hline $\begin{array}{l}\text { ICT } \\
\text { Usage } \\
\rightarrow \quad \mathrm{BP} \\
\text { (c) }\end{array}$ & $\begin{array}{c}0.76 \\
0\end{array}$ & $\begin{array}{c}11.8 \\
2\end{array}$ & 0.091 & 0.023 & 3.92 & 0.851 & 0.106 & $\begin{array}{c}\text { Complem } \\
\text { entary }\end{array}$ \\
\hline $\begin{array}{l}\text { ICT } \\
\text { Usage } \rightarrow \\
\text { BR (a) } \\
\end{array}$ & $\begin{array}{c}- \\
0.61 \\
6 \\
\end{array}$ & $\begin{array}{c}10.3 \\
2\end{array}$ & & & & & & \\
\hline $\begin{array}{l}\mathrm{BR} \\
\mathrm{BP}(\mathrm{b})\end{array}$ & $\begin{array}{c}- \\
0.14 \\
7\end{array}$ & $\begin{array}{c}1.80 \\
1\end{array}$ & & & & & & \\
\hline
\end{tabular}

Source: Survey Data, 2020 
According to Hair et al. (2014), the next step is to study the correlation between independent and dependent variables. According to the given criteria, the model having $\mathrm{R} 2$ as $0.736,0.380$, which are considered as substantial. The last two steps are to examine the effect size and the predictive relevance of the bounded rationality as well as ICT usage on all dimensions according to Cohen (1988) and Chin (1998).

\section{DISCUSSION}

Many researchers have identified the ICT usage creates an avenue for proper information flow between the business parties and eliminate the market barriers which lead to the business performance (Kenneth \& Jane, 2013; Wambaria, et al., 2016). Although it is been in reality researchers do not examine its effect on bounded rationality and conversely, it increases the business performance by reducing bounded rationality. Thus, this study is unique to the literature. First, this study predicts ICT usage positively affects the business performance of SMEs and according to the result ICT usage makes a $76 \%$ contribution to increasing the business performance. These results proved the findings of recently published other researches in the literature. Scholars like BayoMoriones, Billon \& Lera-Lopez (2013 p. 127) said "the number of ICTs has a significant impact on communication improvement. This effect is also found about ICT intensity". The expected performance effects generated on ICT usage in manufacturing SMEs found out that communication development encouraged by ICT adoption leads to better operational performance (positive impact of ICT) and hence, proper communication and operational performance are associated with the better final performance. What is the major effect of enhancing such communication? It reduces the bounded rationality on one hand and reduces the extra cost on other hand. This study found it and according to the result, ICT usage makes a $61.6 \%$ negative impact on bounded rationality. Similarly, Priyanath \& Buthsala (2017) conducted a study on the ability to access information and bounded rationality and found a similar situation and revealed the ability to access information affects $41.4 \%$ $(\beta=0.414$ and $t$-value $=2.5805)$ to enhance the business performance of small businesses of Sri Lanka. Conversely, ICT also totally facilitates the access information and this finding proved it. Bounded rationality is measured by using incapability of access, assess the required business information, and make proper decisions on such information. The findings exhibit that these attributes of bounded rationality make a low negative impact on the business performance including a $14.7 \%$ negative effect on the business performance of SMEs. It is reasonable to understand that the high influence of ICT usage has affected to make a lower effect of bounded rationality. One of the research objectives is been exhibit in this point of view. What is the mediate effect of bounded rationality on the relationship between ICT usage and SME business performance? The above result analysis provides the 
answer and bounded rationality contains a complementary mediate effect on the mentioned relationship.

\section{CONCLUSION}

The study mainly argued that ICT usage boosts business performance because it increases the capability of access, assess, and decision-making on the information as well as reduces the bounded rationality which directly reduces the transaction cost of SMEs and thereby increases the business performance. The study has conceptually buildup a model based on the above relationship and working hypotheses have been established to test it empirically in SMEs in Sri Lanka. The results discovered that ICT usage in the organization makes a significant positive impact on business performance as well as negatively influenced the bounded rationality. Simultaneously, the study uniquely found that bounded rationality makes a negative impact on the business performance of SMEs in Sri Lanka. Meanwhile, the study revealed that bounded rationality plays a dominant role in the relationship between ICT usage and the business performance of SMEs. It means that while the ICT usage is making the $76.0 \%$ positive effect the bounded rationality impels it by $14.7 \%$. According to the research findings, it is reasonable to identify that the Sri Lankan government has implemented more facilities as well as education to enhance the knowledge distribution on ICT, and hence the citizen generally rich in handling digital technology especially mobile equipment as well as internet-based applications.

This research has made several contributions. First, it has developed a distinctive combined model using theoretical bases of ICT usage, bounded rationality, and business performance to understand how ICT usage affects the bounded rationality and business performance in the SME environment. It is a unique contribution and has not been empirically studied by previous researchers. Therefore, this kind of technology and cost-based approach to measuring business performance especially, the SME sector makes valuable insight to understand the practical efficacy of theories. Second, ICT usage has been quantified by this study covering all the available attributes that have not been considered extensively in the past researchers and also the business performance especially, in the context of SME. Thus, it is a vigorous exercise for future researchers on operationalizing this kind of theoretical combination especially, in the SME context. Third, the mediate effect of bounded rationality between the relationship of ICT usage and business performance has not been studied in the past literature and thus this research obtained an opportunity to present it to the research world.

The study recommends policymakers to enhance the existing technologies especially on mobile technologies other than the sophisticated computer-related applications to cater to the access, assess, and evaluation information of SMEs in Sri Lanka. Because receiving such information 
processing facilities through the mobile devices cheaper and hence, the SMEs able to bear the cost other than introducing the computer-related technologies and even all the low literacy people also can effectively utilize the technology. Government and private sector organizations that provide telecommunication facilities can maintain services like mobile applications, mobile data services to enhance the connections between SMEs and the market to avoid the information asymmetry and it will help to make information-rich SMEs network.

This research uses several dimensions of ICT usage as the second-order constructs. The empirical evidence of such dimensions with bounded rationality has not been in the past literature especially, regarding SMEs and it is a prominent starting point. Nevertheless, the technological face of a country can be changed and future researchers should fine-tune and enhance these dimensions as suitable. This research used a relatively small sample against the population. Further researchers are suggested to carry out an extensive study with a larger sample to avoid the far-reaching consequences of generalization problems. The generalization of the research findings will be limited to Sri Lanka. Nevertheless, research findings may not be valid in the context of other countries because ICT usage and business performances become to change with the different cultural backgrounds and socio-economic conditions as well as the bounded rationality. Future researches are suggested to carry out studies in another region of the world with the different cultural and socio-economic background to know how empirical evidence differ from Sri Lanka.

\section{REFERENCES}

Abor, J., \& Quartey, A. (2010). Issues in SME Development in Ghana and South Africa. International Research Journal of finance and Economics, 39(6), 215-228.

Agwu, M. O., \& Emeti, C. I. (2014). Issues, challenges and prospects of small and medium scale enterprises (SMEs) in port-harcourt city in Nigeria.

European Journal of Sustainable Development, 3(1), 101-114.

American Library Association

(ALA). (1989). Presidential Committee on Information

Literacy: Final Report.

Chicago: Author.

Arutè, A., \& Gatautis, R. (2014). ICT Impact on SMEs Performance. Procedia - Social and Behavioral Sciences, 110(2014), 1218-1225.

Bayo-Moriones, A., Billón, M., \& Lera-López, F. (2013). Perceived performance effects of ICT in manufacturing SMEs. Industrial Management \& Data Systems, 113(1), 117135. https://doi.org/10.1108/ 02635571311289700

Bourne, M., Franco, M., \& Wilkes, J. (2003). Corporate performance management. Measuring Business Excellence, 7(3), 1521. 
Carmel, E., \& Nicholson, B. (2005). Small firms and offshore software outsourcing: high transaction costs and their mitigation. Journal of Global Information Management, 13(3), 33-54.

Coase, R. H. (1937). The Nature of the Firm, Economica New Series, 4(6), 386-405.

Cohen, J. (1988). Statistical Power Analysis for the Behavioral Sciences $\left(2^{\text {nd }} E d\right)$. Hillsdale, NJ: Lawrence Earlbaum Associates.

Consoli, D. (2012). Literature analysis on determinant factors and the impact of ICT in SMEs. Procedia - Social and Behavioral Sciences, 62(2012), 93-97.

Cordella, A. (2006). Transaction costs and information systems: does IT add up? Journal of Information Technology, 21(3), 195-202.

Dyer, J. H., \& Chu, W. J. (2003). The role of trustworthiness in reducing transaction costs and improving business performance: empirical evidence from the United States, Japan, and Korea. Organization Science, 14(1), 57-68.

Esselaar, S., Stork, C., Ndiwalana, A., \& Deen-Swarray, M. (2007). ICT usage and its impact on profitability of SMEs in 13 African countries. The MIT Press, 4(1), 87-100.
Fatoki, O. (2011). The impact of human, social and financial capital on the performance of small and medium-sized enterprises (SMEs) in South Africa. Journal of Social Science, 29(3), 193-204.

Fatoki, O., \& Asah, F. (2011). The Impact of Firm and Entrepreneurial Characteristics on Access to Debt Finance by SMEs in King Williams' Town, South Africa. International Journal of Business and Management, Vol. 6(8), 170-179.

Garengo, P., Biazzo, S., \& Bititci, U. S. (2005). Business performance measurement systems in SMEs: A review for a research agenda. International Journal of Management Reviews, 7(1), 25-47.

Giotopoulos, L., Kontolaimou, A., Korra, E., \& Tsakanikas, A. (2017). What drives ICT adoption by SMEs? Evidence from a large-scale survey in Greece. Journal of Business Research, 81(Dec), 60-69. DOI10.1016/j.jbusres.2017.08. 007

Gigerenzer, G., \& Goldstein, D. G. (1996). Reasoning the fast and frugal way: models of bounded rationality. Psychological review, 103(4), 650 - 667.

Glister, P. (1997). Digital Literacy. New York: Wiley.

Haber, S., \& Reichel, A. (2005). Identifying performance 
measures of small ventures: The case of the tourism industry. Journal of Small Business Management, 43(3), 257-287.

Hair, J. F., Hult, G. T. M., Ringle, C. M., \& Sarstedt, M. (2014). A primer on partial Least Squares Structural Equation Modeling (PLS-SEM). Thousand Oaks, California: SAGE Publications.

Hobbs, J. E. (1997). Measuring the Importance of Transaction Costs in Cattle Marketing. American Journal of Agricultural Economics, 79(4), 1083-1095.

Indris, S., \& Primiana, I. (2015). Internal and external environment analysis on the performance of small and medium Industries (SMEs), International Journal of Scientific \& Technology Research, 4(4), 188 -196.

James, A. O'B. (2007). Management Information Systems ( $7^{\text {th }} \mathrm{Ed}$.). McGraw-Hill.

Kathleen, M. W., \& Wilburn, H. R. (2018). The Impact of Technology on Business and Society. Global Journal of Business Research, 12(1), 2339.

Khare, A., Saxsena A., \& Teewari, P. (2012). Supply Chain Performance Measures for gaining Competitive Advantage: A Review. Journal of Management and Strategy, 3(2), 25-32.
Kock, N., \& Hadaya, P. (2018). Minimum sample size estimation in PLS-SEM: The inverse square root and gamma-exponential methods. Information Systems Journal, 28(1), 227-261.

Kuratko, D. F., \& Audretsch, D. B. (2013). Clarifying the domains of corporate entrepreneurship. International Entrepreneurship and Management Journal, 9(3), 323-335.

Lankshear, C., \& Knobel, M. (2003). New Literacies. Changing Knowledge and Classroom Learning. Buckingham: Open University Press.

Lennon, M., Kirsch, I., Von Davier, M., Wagner, M., \& Yamamoto, K. (2003). Feasibility Study for the PISA ICT Literacy Assessment. Report to Network A, OECD Retrieved from http://www.oecd.org/ education/school/programmefo rinternationalstudentassessment pisa/33699866.pdf

Liang, T. P., Huang, C. W., Yeh, Y. H., \& Lin, B. (2007). Adoption of mobile technology in business: A fit-viability model. Industrial Management \& Data Systems, 107(8), 1154-1169. DOI:

$10.1108 /$ 02635570710822796

Markus, A., \& Thomas, H. (2002). Online content syndication - a critical analysis from the perspective of transaction cost theory. ECIS 2002 June 6-8, Gdańsk, Poland. 
Mingle, J., \& Dzandu, M. D. (2013). The Adoption of Information and Communications Technology in the Administration of Health Insurance Schemes in Ghana. International Journal of Computer Science and Network, 2(6), 73-81.

Mithas, S., Tafti, A. R., Bardhan, I., \& Goh, J. M. (2012). Information Technology and Firm Profitability: Mechanisms and Empirical Evidence. MIS Quarterly, 36(1), 205-24.

Nieman, G., Hough, J., \& Nieuwenhuizen, C. (2003). Entrepreneurship: A South African Perspective, Van Schaik, Pretoria, South Africa.

Nguyen, P., \& Crase, L. (2011). Vietnam's state-owned enterprise reform; an empirical assessment in the international multimodal transport sector from the Williamson's TCE perspective. Asia Pacific Journal of Marketing and Logistics, 23(3), 411-422.

Nooteboom, B. (1993). Firm size effect on transaction cost. Small Business Economics, 5, 283-295.

O’Regan, N., \& Ghobadian, A. (2004). Leadership and Strategy: Making it Happen. Journal of General Management, 29(3), 76-92. https://doi.org/10.1177 /030630700402900305

Pham, Q. T. (2010). Measuring the ICT maturity of SMEs. Journal of Knowledge Management Practice, 11(1), 34 - 51.

Pham, X. K., Le, N. S., \& Nguyen, T. P. G. (2013). Measuring the ICT maturity of enterprises under uncertainty using group fuzzy ANP. International Journal of Machine Learning and Computing, 3(6), 524 528.

Prasad, S., Tata, J., \& Guo, K. (2012). Sustaining small businesses in the United States in times of recession: Role of supply networks and social capital. Journal of Advances in Management Research, 9(1), 8 - 28 .

Priyanath, H. M. S., \& Premarathne, S. P. (2014). Government SME development programs in Sri Lanka: A review in the lens of transaction cost economics. Sabaragamuwa University Journal, 13(2), 59-81.

Priyanath, H. M. S., \& Buthsala, W. K. A. (2017). Information, opportunism and business performance: a case of small businesses managed by women entrepreneurs in Sri Lanka. Asian Journal of Multidisciplinary Studies, 5(11), 230 - 239.

Priyanath, H. M. S., \& Premarathne, S. P. (2017a). Power of social capital on mitigating transaction cost of small enterprises in Sri Lanka: An empirical investigation. International Journal of Arts and Commerce, 6(4), 17 -35. 
Priyanath, H. M. S., \& Premarathne, S. P. (2017b). Effect of information access through social capital on mitigating business opportunism of small enterprises in Sri Lanka. Colombo Business Journal, $8(2), 42-67$.

Priyanath, H. M. S., \& Premarathne, S. P. (2017c). The effect of inter-personal trust on transaction costs of ownermanaged small enterprises in Sri Lanka. Sri Lanka Journal of Economic Research, 5(1), 1 29.

Priyanath, H. M. S. (2017). Effect of network structure on transaction cost of small enterprises in Sri Lanka: An empirical study. Journal of Small Business and Entrepreneurship

Development, 5(1), 19-34.

Ranatunga, R. V. S. P. K., Priyanath, H. M. S., \& Megama, R. G. N. (2020). Digital Literacy, Business Uncertainty \& Economic Performance: An Empirical Study of Small Businesses in Sri Lanka. International Journal of Academic Research in Business and Social Sciences, 10(5), 5076.

Richard, P. J., Devinney, T. M., Yip, G. S., \& Johnson, G. (2009). Measuring Organizational Performance: Towards Methodological Best Practice. Journal of Management, 35(3), 718-726, DOI: $10.1177 / 0149206308330560$
Sabbagh, K., Friedrich, R., ElDarwiche, B., Singh, M., Ganediwalla, S. \& Katz, R. (2012). Maximizing the impact of digitization, in Dutta, S. and Bilbao-Osorio, B. (Eds), The Global Information Technology Report, World Economic Forum and Insead, Geneva.

Santos, J. B., Brito, L. A. L. (2012). Toward a Subjective Measurement Model for Firm Performance. BAR - Brazilian Administration Review, 9(9), 95-117. DOI: 10.1590/S180776922012000500007

Saunila, M. (2016). Performance measurement approach for innovation capability in SMEs. International Journal of Productivity and Performance Management, 65(2), 162-176.

Shamsuzzoha, A. H. M., Helo, P., \& Sandhu, M. (2017). Virtual enterprise collaborative processes monitoring through a project business approach, International Journal of Computer Integrated Manufacturing, 30(10), 10931111, DOI: 10.1080/0951192X.2017.1285 427

Simpson, M., Tuck, N., \& Bellamy, S. (2004). Small business success factors: the role of education and training. Education and Training, 46(8/9): 481-491.

Tarute, A., \& Gatautis, R. (2014). ICT impact on SMEs performance. Social and 
Behavioral Sciences, 110, 1218-1225. DOI: 10.1016/j.sbspro.2013.12.968

Walker, E. A., Brown, A. (2004). What success factors are important to small business owners?, International Small Business Journal, 22(6), 577594.

Wambaria, D. W., Kibas, P. B., \& Asienga, I. C. (2016). Determining business environmental factors in ICT adoption by SMEs owner managers in rural Kenya. International Journal of Economics, Commerce and Management, 4(10), 1180 1196.

Waśniewski, P. (2017). A performance measurement system for small enterprises - a case study. Zeszyty Teoretyczne Rachunkowości, 93(149), 211233.

Williamson, O. E. (1981). The economics of organization: transaction costs approach. American Journal of Sociology, 87(3), 548-577.

Williamson, O. E. (1985). The Economic Institutions of Capitalism. Free Press, New York.

Yazdanfar, D., \& Öhman, P. (2014). Life cycle and performance among SMEs: Swedish empirical evidence. The Journal of Risk Finance, 15(5), 555-571.
Yoshino, N., \& Taghizadeh-Hesary, F. (2016). Major Challenges Facing Small and MediumSized Enterprises in Asia and Solutions for Mitigating Them. ADBI Working Paper 564, Available at SSRN: https://ssrn.com/abstract=2766 242 or http://dx.doi.org/10.2139/ssrn.2 766242

Zhang, A. (2009). Corruption as a determinant of transaction governance structure. Strategic Outsourcing: An International Journal, 2(1), 27-36.

Zhao, X., Lynch, J. G., Jr., \& Chen, Q. (2010). Reconsidering Baron and Kenny: Myths and truths about mediation analysis. Journal of Consumer Research, 37(2), 197-206. https://doi.org/10.1086/651257 